\section{EFFECTS OF TEACHING ALEARNING PSYCHOLOGY COURSE IN DIFFERENT WAYS ON THE STUDENT'S SUCCESS AND ATTITUDES}

\begin{abstract}
The aim of this study is to determine the effect of teaching a learning psychology course in different ways on students' academic success and attitudes towards the course. The experimental research method was used in this research. The participants were students in the second year of a psychological counseling and guidance program in a state university in Turkey. The data were collected by Learning Psychology Course Achievement Test and student letters. ANOVA, Kruskal Wallis and Wilcoxon Signed Rows test were used in the analysis. Student letters were analyzed through content analysis. In the first group, the lecturer taught the class interactively each week with the presentations prepared by the researchers. In the second group, no lectures were made in this group. At the beginning of the lesson each week, students were given the outputs of the presentations and the lesson was carried out with two activities each week. In the third group, the flipped learning model was applied in this group. As a result of the study, it was concluded that the standard deviation was smaller in the group in which the flipped learning model was applied compared to the other two groups.
\end{abstract}

\section{KEYWORDS}

Flipped learning model, learning psychology course, student attitude, student-centered education, student success

\section{HOW TO CITE}

Şahin Ş., Ökmen B., Kılıç A. (2020) 'Effects of Teaching the Learning Psychology Course in Different Ways on the Student's Success and Attitudes', Journal on Efficiency and Responsibility in Education and Science, vol. 13, no. 3, pp. 113-129. http://dx.doi. org/10.7160/eriesj.2020.130302

\section{Şeyma Şahin \\ Burcu Ökmen \\ Abdurrahman Kılıç \\ Düzce Üniversitesi, Turkey \\ burcuokmen91@hotmail.com}

\section{Article history}

Received

April 22, 2020

Received in revised form

March 15, 2020

Accepted

July 31, 2020

Available on-line

September 30, 2020

\title{
Highlights
}

- The students' learning performances were close to each other, and the students in the whole group learned well.

- The standard deviation was smaller in the group in which the flipped learning model was applied. This shows that the flipped learning model is effective on students' success.

- The students in the flipped learning group liked the lesson very much, found the lesson efficient, had fun, and were surprised at how quickly time passed.

- The students in the flipped learning group thought that group studies contributed to their exchanges of ideas with their friends, getting to know each other, and learning from each other.

\section{INTRODUCTION}

Global changes in science and technology have had a significant impact on education as well as many other fields (Benson, 2012). The purpose of education today is to train students who can solve problems, adapt their knowledge to real life, work collaboratively, and engage in lifelong learning (Hains and Smith, 2012). For this reason, educational environments in which the student merely watches on the sidelines and the teacher works as the only actor in the classroom cannot attract the attention of the students. It is not possible to have effective and permanent learning in such environments (RodriguezValls and Ponce, 2013).

The strength of student-centered education comes from the fact that it allows students to learn from their own experience, to structure information, and to reflect on it (Daley, 2003). Scientific research supports student-centered education. Studies show that student-centered education increases 
students' motivation for learning, increases the level of this creates difficulties for students who do not have individual knowledge recall, provides in-depth knowledge, and has learning habits. There are studies that say that the obligation positive effects on creavity, critical thinking, sucess, student to work at home is a disadvantage of this model (Alseck participation, student satisfaction, student self-esteem, and Sirakaya, 2015. Turan and Goktas, 2015). Considering these learning motivation (Kulc and Sahin, 2016; Maden, Durukan disadvantages of flipped learning in the literature, in this study and Akbas, 2011: Salinas, Kane-Johnson and Vasil-Miller, students in one group were taught using a different model 2008. Scott, Buchanan and Haigh, 1997. Smart and Csapo, suitable for student-centered understanding. In this model, 2007). Effective teaching practices can be implemented by using different methods and techniques in line with studentcentered education principles. Teachers should learn and try different methods and techniques in order to better respond to students' interests, wishes, and needs and to organize the to students interests, wishes, and needs and to organize the
classroom better (Ha, 2013). When the results of the research in the literature are examined, it is seen that student-centered strategies, methods, and techniques such as project-based learning, inquiry-based learning, problem-based learning,
collaborative learning, and flipped learning are used, which are collaborative learning, and flipped learning are used, which are
effective in increasing academic success (Baepler, Walker and Driessen, 2014; Donovan and Lee, 2015; Green, 2015; Harvey, 2014; Lazonder and Harmsen, 2016; McCallum et al., 2015; Vernon and Blake 1993)

Within the scope of this research, it was aimed to conduct a course effectively while using different teaching methods to make the students active. For this reason, three different lesson designs of different styles and levels were prepared, each aiming to bring the students to the center and make them active. By comparing these lesson designs, it was aimed to reveal the advantages and disadvantages of each and thus guide teachers who want to use different methods and techniques in their classrooms.

One of the student-centered strategies used in this research is the flipped learning model. The flipped learning model is a model that includes traditional learning in the classroom and approach and has become quite popular recently (Bergmann and Sams, 2012; Tucker, 2012). Flipped learning is one of the models used by integrating technology into student-centered education. With the introduction of technology into educationa environments, it allowed the design of teaching material suitable for different student characteristics, and beside enriching the educational environments, it enabled efficien learning environments to be created by facilitating accessibility ofeducational environments (Nemtchinova, 2007). According to Sams and Bergmann (2013), the main component of the flipped learning model is increasing the quality of face-to-face education by using the most efficient time spent at school with students. It is stated that the work done at home increases the students' active participation and success (Frydenberg, 2012 Okmen, 2020; Stone, 2012; Talbert, 2012). While student acquire lower-level information outside the classroom through
technology, they use their higher-level thinking skills with technology, they use their higher-level thinking skills with teachers and classmates in the classroom (Bergmann and
Sams, 2012).

In addition to these positive features, some negative features of the flipped learning model are also mentioned in the literature.

Talbert (2012) states that in this model, students should work

individually at home and watch the content of the lessons, bu the home learning section, which is seen as a disadvantage and learning was carried out only at school. In this way, it was ested whether a new model could be introduced by producing solution to the disadvantageous parts of the flipped learning model.

In the third model applied within the scope of the research, the course was taught in the style of presentations, but interaction was provided with the students using the question-and-answer as a way to make students effective, is a technique used to learn what students understand, to increase their interest in the lesson, and to develop higher-level thinking skills (Kubat, 2018). While teachers determine the level of learning through manner, they offer the student the opportunity to learn a new opic (Buyukalan Filiz, Celik, and Toraman 2018). Although he question-and-answer method does not fully comply with the student-centered understanding, the effect of asking students for examples, interactive lesson processing, and equesting a portfolio with the requested homework at the end of the course was investigated and the effects of this method were compared with the other methods.

In this study, it was aimed to conduct lessons effectively by using different teaching methods to make the students active nd to make comparisons between these three models used in the course process. In this context, the aim of this study is to determine the effect of teaching a learning psychology course different ways on students' academic success and attitudes the course. This basic purpose has been applied to .

What is the effect of teaching a learning psychology
course in different ways on students' academic success?

\section{MATERIALS AND METHODS}

This section includes information on the research model, working group, application process, data collection, data

\section{Research Mode}

Experimental research method was used in this research. Expermental researches are studies to test the effect of differences created by the researcher on the dependent variable (Buyukozturk et al., 2013). "Pretest-posttest group design" was used to deternmine the efred of ho couse on stedents" acalonic achievement. Each of the groups in the design was echnique. The question-and-answer technique, which is seen questions and whether learning takes place in an organized

What are the opinions of the students about the lessons? de design was given in Table

\begin{tabular}{c|c|c|c} 
& Pretest & Treatment & Posttest \\
\hline$E_{1}$ & $P_{1}$ & $X_{1}$ & $P_{4}$ \\
\hline$E_{2}$ & $P_{2}$ & $X_{2}$ & $P_{5}$ \\
\hline$E_{3}$ & $P_{3}$ & $X_{3}$ & $P_{6}$ \\
\hline
\end{tabular}

E1: Experiment Group-1, E2: Experiment Group-2, E3: Experiment Group-3

P1,2,3: Pretest, P4,5,6: Posttest

X1: Experiment Process-1, X2: Experiment Process-2, X3: Experiment Process-3

\section{Table 1: Pretest-Posttest Research Design}

\section{Working Group}

The participants were Psychological Counseling and Guidance program students studying in 2 nd class in a state the "convenient sampling" method. Convenient sampling is based on the items that are available, fast and easy to reach (Baltac1, 2018). In this study, the students of the three classes

\begin{tabular}{|c|c|c|c|c|c|c|}
\hline & $N$ & Mean & Standard Deviation & $d f$ & $\boldsymbol{F}$ & $p$-value \\
\hline Group 1 & 31 & 2.87 & 0.25 & & & \\
\hline Group 2 & 21 & 2.96 & 0.31 & 2 & 0.96 & 0.39 \\
\hline Grop 3 & 34 & 2.88 & 0.18 & & & \\
\hline
\end{tabular}

\section{Table 3: ANOVA Test Results Regarding GPA Scores of Groups}

As can seen in Table 3, according to the ANOVA test In order to determine the equivalence of the groups in terms results, there was no significant difference between the of information related to the course, "learning psychology it can be said theres $(F=0.961, p>0.05)$. In this case, course pre-test" was applied before the research. ANOVA GPA scores.

\begin{tabular}{|c|c|c|c|c|c|c|}
\hline & $N$ & Mean & Standard deviation & $d f$ & $F$ & $p$-value \\
\hline Group 1 & 31 & 46.65 & 6.68 & & & \\
\hline Group 2 & 21 & 47.43 & 9.06 & 2 & 0.35 & 0.71 \\
\hline Group 3 & 34 & 45.41 & 10.86 & & & \\
\hline
\end{tabular}

Table 4: ANOVA Test Results Regarding the Pretest Scores of the Groups

As seen in Table 4, ANOVA test did not show any significant difference between the groups according to the pretest results $(F=0.35, p>0.05)$. In this case, it can be said that the information of each group was equivalent to each other before the applications.

\section{Application Process}

The application process of the research was carried out by the lecturer and two doctoral students who are responsible for conducting the course at the university. Before this application, a tem plan was prepaed for ech group by the researchers. The learning psychology course, which lasted 14 weeks in total, was held on Wednesday each week in three groups. In the first three weeks, basic information was given in all groups and pretesting was applied. Experimental application started on 4 weck and lasted for a total of 11 weeks. The evaluation or the the end of 14 weeks, the final test that replaced the fina

The numbers of females and males in the working groups

\begin{tabular}{l|c|c|c} 
& Female & Male & Total \\
\hline $1^{\text {st Group }}$ & 25 & 12 & 37 \\
\hline $2^{\text {d }}$ Group & 19 & 9 & 28 \\
\hline $3^{\text {dd }}$ Group & 28 & 12 & 40 \\
\hline Total & 72 & 33 & 105 \\
\hline
\end{tabular}

Table 2: Number of Working Group Students

As can be seen in Table 2, there are 105 students in the study group. There are 37 students in the first group, 28 students in the second group and 40 students in the third oup. 72 students are females and 33 are males.

order to determine the equivalence of the groups, it between the students' GPA (Grade Point Average) scores. GPA of the students were obtained from the university system. ANOVA test results for this purpose were given fore put this homework in their portfolios. As homework, tasks university in Turkey. The working group was determined by

\section{First Group}

Int group, the lecturer taught lesson interactively each Wek through the presentation prepared by the researchers. During the lesson, the examples in the presentation were given and students were asked to create various examples. 政 thson with various stories, jokes and memories. The the presentation was distributed to the students the such as preparing questions, writing examples, finding similarities and differences, preparing concept maps, preparing puzzles, writing acrostic or poetry, writing slogans, writing the reflection of theories on education were given. 


\section{Second Group} lesson each week, students were given the outputs of the test were university students who

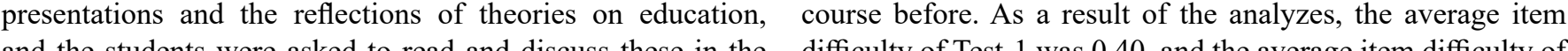
first weeks individually and in the next weeks in this, students were given 20-30 minutes. After that the lesso was carried out with two activities each week, which male it necessary to use the information on the subjects. In this process; snowball, station, bearing thinking with six bas, fishbone, butter-bread, aquarium, drama techniques; writing poetry, completing stories, preparing puzzles, writing letters, matching cards, drawing questions from the jar, finding similarity-difference, preparing a concept map, structured grid activities were used. In this group, no assignment was given for the pre-class and post-class learning period. The students were asked to put their studies in their portfolios. Student were given compensatory duties for weeks when they couldn't attend classe

\section{Third Grou}

The flipped learning model was applied in this group. Lecturing videos were taken through the presentations prepared for each lesson. Before the lesson, the lecturing videos and a document were asked to watch the video, write the examples, read the document about the reflection of the theory on education and do the task (preparing a question, summarizing and answering the given question). Before the students came to class, they sent their tasks to the researchers via WhatsApp and received the necessary feedback. In the course, three different activities were organized for the students each week. In this process; snowball, station, bearing, thinking with six hats, fishbone, butter-bread, aquarium, drama techniques; writing poetry, completing stories, preparing puzzles, writing letters, matching cards, drawing questions from the jar, finding similarity-difference, preparing a concept map, structured grid activities were used. In this group, no assignment was give for the pre-class and post-class learning period. The students were asked to put their studies in their portfolios. Students were given compensatory duties for weeks when they couldn't attend classes.

\section{Data Collection}

The data were collected by "Learning Psychology Course Achievement Test" and student letters.

\section{Learning Psychology Course Achievement Test}

In this research, "Learning Psychology Course Achievement Student letters were analyzed through content analysis. Content Test "was developed to meastro the academic success levels analysis is defined as a detailed and careful examination of of the students at the end of the application. First of all, a pacticular material to define patterns, categories or meanings a table of specifications was prepared in order to ensure the (Leedy and Ormrod, 2005, Neuendorf and Kumar, 2002). The content validity. Within the scope of this specifications table, data analysis process was carried out in three stages (Kilic et a question pool consisting of researchers. A pilot application was carried out to ensure the tirterpreting. The data were combined and grouped and made validity and reliability of the achievement test. For this purpose, ready for analysis at the stage of organizing data. The forms two sepante plot test forms wih 109 questions in the question were also pool were prepared. Test-1 form consisting of 55 questions used in direct quotes. During the stage of summarizing data; coding and classification processes were carried out. The dat were coded by two researchers, then the codes were compare and the missing ones were completed. Later, during the stage of the classification stage, these codes were collected under

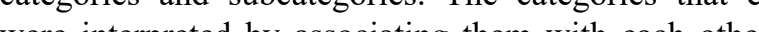
stage of association/interpretation.

\section{Validity-Reliability}

Kuder Richardson-20 (KR-20) reliability was used to examine the internal consistency of the achievement test. As a result of the calculation, the reliability coefficient of Test-1 (KR-20) was 0.806 , and the reliability coefficient of Test-2 (KR-20) was 0.861 . Tests with a reliability coefficient of 0.70 and above and Wallen, 2000). In this case, both tests can be said to be reliable.

The data collection and analysis process is explained in detail for the validity and reliability of qualitative data. In the conten analysis, the creation of categories was done meticulously The content analyzed data was coded separately by two researcher. The consistency was calculated using the reliability formula proposed by Miles and Huberman (1994) and the agreement between the codings was found to be $89 \%$ compliance. Missing codes were examined by examining non- agreement codes. Objectivity was tried to be obtained through direct quotation from student letters. All raw data of the study was filed and stored for review.

RESULTS

In this research work, after the analysis of qualitative and quantitative data, the findings of each data type were presented separately. Results were gathered under the titles of "academic success" and "opinions about the conduction of the course."

\section{Academic Achievements}

Academic success was examined under the titles which are

\begin{tabular}{|c|c|c|c|c|c|}
\hline & $N$ & Mean rank & Sum of ranks & $z$-value & $p$-value \\
\hline \multirow{3}{*}{ Group 1} & 0 & 0.00 & 0.00 & -4.86 & 0.00 \\
\hline & 31 & 16.00 & 496.00 & & \\
\hline & 0 & & & & \\
\hline \multirow{3}{*}{ Group 2} & 0 & 0.00 & 0.00 & -4.02 & 0.00 \\
\hline & 21 & 11.00 & 231.00 & & \\
\hline & 0 & & & & \\
\hline \multirow{2}{*}{ Group 3} & 0 & 0.00 & 0.00 & -5.09 & 0.00 \\
\hline & 34 & 17.50 & 595.00 & & \\
\hline
\end{tabular}

Table 6: Wilcoxon Signed Ranks Test Results Regarding Pretest-Posttest Scores

When Table 6 is examined, it is seen that there is a significant Comparison of the Posttest Scores of the Group difference between the pre-test and post-test scores of the students who take "learning psychology course success test". They are Kruskal Wallis test was performed to determine whether $(z=-4.86, p<0.001)$ in Group $1,(z=-4.02, p<0.001)$ in Group 2 and there was a significant difference between the post-test scores $(z=-5.09, p<0.001)$ in Group 3. It is seen that these differences are in favor of the post-test in each group. In this case, it can be said that results regarding the posttest scores of the groups were given the operations performed in each group positively affected learning. in Table 7: 


\begin{tabular}{c|c|c|c|c|c} 
& $N$ & Mean rank & Standart deviation & $X^{2}$ & $p$-value \\
\cline { 1 - 2 } Group 1 & 31 & 43.08 & \multirow{2}{*}{2} & \multirow{2}{*}{0.01} & 0.99 \\
\cline { 1 - 2 } Group 2 & 21 & 43.64 & 2 & & \\
\hline Group 3 & 34 & 43.79 & & & \\
\hline
\end{tabular}

Table 7: Kruskal Wallis Test Results Regarding Posttest Scores

As seen in Table 7, no significant difference was detected were taught interactively with the students through slides As seen in Table 7, no significant difference was detected
between the posttest scores of the groups $\left(X^{2}=0.01, \quad\right.$ are discussed interactively with the students through slides
$p>0.05)$ headings which are "Views on

$\begin{array}{ll}p>0.05) \text {. This shows that the applications done on three the design of the course", "opinions on examples, stories } \\ \text { different groups do not differ academically. } & \text { and memories" and "opinions on homework". }\end{array}$

\section{Student Opinions}

\section{Opinions on the Design of the Course}

The opinions of the students about the conduction of The opinions of the students in the first group regarding the course were examined separately for each group. the design of the course were given in Table 8:

\section{Opinions of the Students in the First Group}

Opinions of the students in the first group, where courses

\begin{tabular}{|c|c|c|}
\hline \multirow{5}{*}{ Positive Views } & gories & Codes \\
\hline & Learning & $\begin{array}{l}\text { Giving lecture is useful and efficient. } \\
\text { It was impossible to understand the lecture without listening. } \\
\text { This style of learning is better than the ones in other groups. } \\
\text { The distributing presentations' printouts was effective in learning. } \\
\text { Enabled the subject to perceive as a whole. }\end{array}$ \\
\hline & Course Participation & $\begin{array}{l}\text { There was an active lecture giving. } \\
\text { Student was also effective in giving lecture. }\end{array}$ \\
\hline & Permanence & The information was catchy. \\
\hline & Attractiveness & $\begin{array}{l}\text { The course was interesting and beautiful. } \\
\text { I came to lecture willingly. } \\
\text { I hung on the course's every word. } \\
\text { I left the class happily. } \\
\text { I lexcitedly waited for the next course. }\end{array}$ \\
\hline \multirow{5}{*}{ Negative Views } & Learning & I would understand better with the station technique. \\
\hline & Course Participation & $\begin{array}{l}\text { I tried to participate in the course, but I could not. } \\
\text { Slides were read in the course, and the students could not participate. } \\
\text { I did not attend the course, and I do not like to attend anyway. } \\
\text { It should have been interactive. }\end{array}$ \\
\hline & Permanence & $\begin{array}{l}\text { Subject teaching is not permanent. } \\
\text { I noticed that I forgot the information right after the course. }\end{array}$ \\
\hline & Attractiveness & $\begin{array}{l}\text { It wasn't fun like the other group. I would love to try it. } \\
\text { Using the same method every week caused fading. } \\
\text { Plain lecturing was not nice. } \\
\text { The course was boring. } \\
\text { I was tired at the end of the course. } \\
\text { Sometimes I was sleepy in the course. } \\
\text { The content caused students to lose attention. } \\
\text { The course time was long. }\end{array}$ \\
\hline & Diversity & $\begin{array}{l}\text { It would have been nice to done some activities during the course. } \\
\text { Different materials should have been used. } \\
\text { There should have been different methods and techniques. } \\
\text { It was upsetting that the station techniques was not used. }\end{array}$ \\
\hline
\end{tabular}

Table 8: Opinions on the Design of the Course

As can be seen in Table 8, the students' views on the design of negative in terms of student participation. The students think that the course were categorized under two categories as "positive the course is not interactive and they cannot participate in the opinions" and "negative opinions". course with this method. There are two different opinions that the It is seen that students have positive and negative opinions about course provides permanence and not. When positive opinions are the way the course is taught. Although it is stated that this method examined in terms of attractiveness, it is seen that some of the has a positive effect on attendance, it is seen that the method is students love the course, attend it intentionally and leave it happily.
It is striking that some of them dislike the course and think it is long, tiring and boring. In the Diversity subcategory, it is observed that students want to do activities, learn with fun, use different materials with different methods and techniques. Although they want to learn with diversity and fun and do not find the course very interesting, it is discovered that students generally think that they understand the course better in this way. It is noticed that students think that good learning is provided through lecture giving it is not possible to understand the course without listering and they are able to perceive the subject as a whole very well in this way. Some direct quotes are given below:

\begin{tabular}{cc} 
Categories & Given by the teacher \\
Positive Opinions & \\
\cline { 2 - 3 } & $\begin{array}{c}\text { Requested from } \\
\text { student }\end{array}$ \\
Negative Opinions & \\
\hline
\end{tabular}

S9: "I think it is more beneficial to carry out the course in the form of a station technique. Because plain lecturing and giving homework is not interesting." S19. "I think just giving examples in the course, which rarely happened, was not enough. I was trying to participate more in the course and digest the content bit wenforture thely this was not always not always happening."

\section{Opinions on Examples, Stories and Memories}

The opinions of students in the first group regarding examples, stories and memories were given in Table 9:

\section{Table 9: Opinions on Examples, Stories and Memories}

As can be seen in Table 9, students' opinions about examples, stories and memories are categorized under two categories as "positive opinions" and "negative opinions".

homework were given in Table 10 It is seen that students have positive and negative opinions As can be seen in Table 10, students' views on homework are about the examples, stories and memories in the course, but categorized under two categories as "positive opinions" and positive opinions are quite high. The students think that the "negative opinions".

examples given by the teacher, the stories and memories he It is observed that students have both positive and negative views tells are interesting and beautiful, are effective in learning, and towards homework. Some of the students think that homework are useful in terms of permanence and strengthening. It is also offers the opportunity to repeat topics, strengthen the course and seen that students find it effective and beneficial to be asked contribute positively to their learning. It is seen that some students for samples and thus they feel active in the course. However, think that homework such as acrostic, poetry, writing slogans are there are also some students who think that there are not unnecessary and useless, they should be done during the course enough examples given by the teacher and that they cannot give enough examples.

Some direct quotes from students' opinions under these categories are given below:

S27: "When you give examples in the course, you give very similar examples or I confuse them because the theories are similar. My request to you is to give wide variety of examples, not only through us or similar things, while giving examples in the lesson."

S28: "The examples given in the course and you memories that you shared with us were very nice. Occasionally, when you take examples from us and use it in the course helped us learn many things."

instead of being given as homework, and homework should be checked daily

There are students who find their homework interesting as well is not interesting. It is discovered that students generally find homework difficult. It is seen that students think that homework requires skills, takes a lot of time, is tiring and causes stress.

Some direct quotes from students' opinions under these categories are given below:

S30: "Some homework's contents such as slogan and acrostic push me very hard. These make me say 'What is it about?'." S33: "It was nice that you make us write questions. Even Though It sounded very simple, it was a homework that at least measure if we really understand the subject." 


\begin{tabular}{|c|c|c|}
\hline \multirow{4}{*}{ Positive Opinions } & \multicolumn{2}{|r|}{ Question preparation assignments were efficient. } \\
\hline & Easiness & It was not difficult. \\
\hline & Permanence & Ensured permanence \\
\hline & Attractiveness & $\begin{array}{l}\text { It provided learning with fun. } \\
\text { It was interesting and fun. } \\
\text { It was done with love. }\end{array}$ \\
\hline \multirow{3}{*}{ Negative Opinions } & Learning & $\begin{array}{l}\text { Acrostic, poetry, slogan, etc. were illogical, unnecessary, useless. } \\
\text { I wish there were no homework. } \\
\text { There should have been quizzes instead of homework. } \\
\text { Homework should have been done during the course time. } \\
\text { Homework should have been checked day by day. } \\
\text { Homework was not useful. }\end{array}$ \\
\hline & Easiness & $\begin{array}{l}\text { Homework such as acrostic, poetry and slogan required creativity. } \\
\text { Some homework was difficult. } \\
\text { Doing homework every week was tiring. } \\
\text { Homework took a lot of time. } \\
\text { Homework was a burden. } \\
\text { Homework was a stress factor. }\end{array}$ \\
\hline & Attractiveness & $\begin{array}{l}\text { Doing homework was not interesting. } \\
\text { The homework was overwhelming }\end{array}$ \\
\hline
\end{tabular}

\section{Table 10: Opinions about Homework}

\section{Opinions of the Students in the Second Group}

The opinions of the students in the second group, where the activities were done in groups by reading the presentation without any lecture, are gathered under three categories which are "opinions about the design of the course", "opinions abou the reading task" and "opinions about the activities".

\section{Opinions on the Design of the Course}

The opinions of the students in the second group regarding the design of the course were given in Table 11:

As can be seen in Table 11, students' opinions on homework are categorized under two categories as "positive opinions" and "negative opinions".

It is seen that students have positive and negative opinions In examined, it is observed that students have mostly negative reading task consist of only one category, "negative ppinions about this method in terms of education, but they opinions".

have mostly positive opinions about attractiveness. This It is seen that the students do not have a positive opinion situation shows that students find the way the course is taught about asking them to learn the subject by reading the is fun and intesting, but they are worried about not learning. documents given to them at the beginning of the course. While, in the first group, the opposite was true. It was seen that It is noteworthy that all of the students' opinions on this the students generally did not find the course interesting, but issue are negative. The thing that the students complain the they thought it had a positive effect on learning. This situation most is that the duration is not enough. In addition, it is shows that students have the idea that they learn better with observed that they were both ned since they had to read the the traditional method. It is also observed that students have documents within a certain period of time. Moreover, also positive opinions about this method that it provides active observed that they think that they did not understand and did participation and free self-expression in the course.

Some direct quotes from students' opinions under these Some direct quotes from students' opinions under these categories are given below:
S2: "I had fun in some activities, I got bored in others, Io the teaching of the course to me. I am a kind of person who understands better when teacher explains." I think I have reached a certain level of knowledge

\section{Opinions on Reading Assignment}

categories were given below.
S4:" "Overall, it was a fun course. But my expectation was

Attractiveness It was the first time in my life that I had such a course. It was student-centered. It was better than listening to the teacher with being bored. I did not understand how time passed. Many subjects have been wasted. This process did not work in learning.
We couldn't learn effectively and properly.

Learning I would prefer the subject to be taught. We deflected from the focus. I had difficulties in learning. I prefer to listen teacher and take notes.

列

Attractiveness I couldn't like the course. did not have motivation to come and participate the course. The structure of the

Leaving the responsibility to the student did not make me happy. It was not an appropriate processing in terms of class size an

Applicability duration.

Table 11: Opinions on the Design of the Course

\begin{tabular}{|c|c|c|}
\hline \multicolumn{2}{|c|}{ Categories } & Codes \\
\hline \multirow{4}{*}{ Negative Opinions } & Limited Time & $\begin{array}{l}\text { We could not finish reading the handed papers. } \\
\text { The time given to read was insufficient. } \\
\text { I can learn by reading one by one, I couldn't catch up. } \\
\text { It is not appropriate to assume that everyone can to read at the same } \\
\text { time. }\end{array}$ \\
\hline & Designated Time & $\begin{array}{l}\text { Reading a slide in a period of time put me in stress. } \\
\text { Information should have been given before the course. } \\
\text { Course notes should have been given in advance. }\end{array}$ \\
\hline & $\begin{array}{l}\text { Inability to } \\
\text { Understand the } \\
\text { Subject }\end{array}$ & $\begin{array}{l}\text { I read without understanding. } \\
\text { I have read just enough to do the activities. } \\
\text { I could not understand the subject by reading. } \\
\text { Without understanding the subject, we moved on to the activity. } \\
\text { We couldn't get the necessary information just by reading the } \\
\text { presentations. }\end{array}$ \\
\hline & Other & Reading in pairs was not efficient. \\
\hline
\end{tabular}

\section{Table 12: Opinions on Reading Assignment}

S5: "The problem for me was that the time was short. We read the form in a short period of time and started witing poem. I started writing poen before I could finish reading the form. Thus, I didn get any yield."
S8: "I think that more time should be given while reading the course notes. Because, performing the application before it was clearly understood and thinking about timing, caused both the application not to be understood and taking more time while the application was done." 
The opinions of the students in the second group regarding the As can be seen in Table 13, students' opinions on activities consist of activities were given in Table 13 .

\section{Categories}

\begin{tabular}{|c|c|c|}
\hline & & \\
\hline \multirow{5}{*}{ Positive Opinions } & Learning & $\begin{array}{l}\text { The activities were useful, provided learning. } \\
1 \text { learned the subject in class with activities. } \\
\text { We learned how to use of methods and techniques. }\end{array}$ \\
\hline & Participation & Even the student who never participated was actively involved. \\
\hline & Permanence & During the finals week, I realized that the activities were permanent. \\
\hline & Group Interaction & $\begin{array}{l}\text { Group interaction was nice. } \\
\text { I spoke / communicated with people I never spoke to. } \\
\text { I united with my classmates. }\end{array}$ \\
\hline & Attractiveness & $\begin{array}{l}\text { The activities were fun. } \\
\text { The activities were varied and beautiful. }\end{array}$ \\
\hline \multirow{5}{*}{ Negative Opinions } & Learning & $\begin{array}{l}\text { Activities were like games, not like learning activities. } \\
\text { The activities were not instructive / useful. } \\
\text { There were no warnings or corrections in the activities. } \\
\text { The activities were not instructive since the subject was not } \\
\text { understood. } \\
\text { The methods could not be used for learning purposes. }\end{array}$ \\
\hline & Limited Time & $\begin{array}{l}\text { Activities were rushed, they should have been done slowly. } \\
\text { The time was short. } \\
\text { The time could not be used properly / time was wasted. }\end{array}$ \\
\hline & Attractiveness & $\begin{array}{l}\text { Some activities were boring. } \\
\text { We did not do the tasks willingly. }\end{array}$ \\
\hline & Group Interaction & $\begin{array}{l}\text { There was no respect for someone else's ideas. } \\
\text { There were some problems in group works. } \\
\text { Working as a group was not good. } \\
\text { Everyone in the group did not fulfill their responsibilities. } \\
\text { Some people in the group assumed the duties. }\end{array}$ \\
\hline & Other & $\begin{array}{l}\text { There was a lot of noise during the events. } \\
\text { I felt uncomfortable reading the activities from the blackboard. } \\
\text { Photocopying the activities was a problem. }\end{array}$ \\
\hline
\end{tabular}
two categories which are "positive opinions" and "negative opinions".

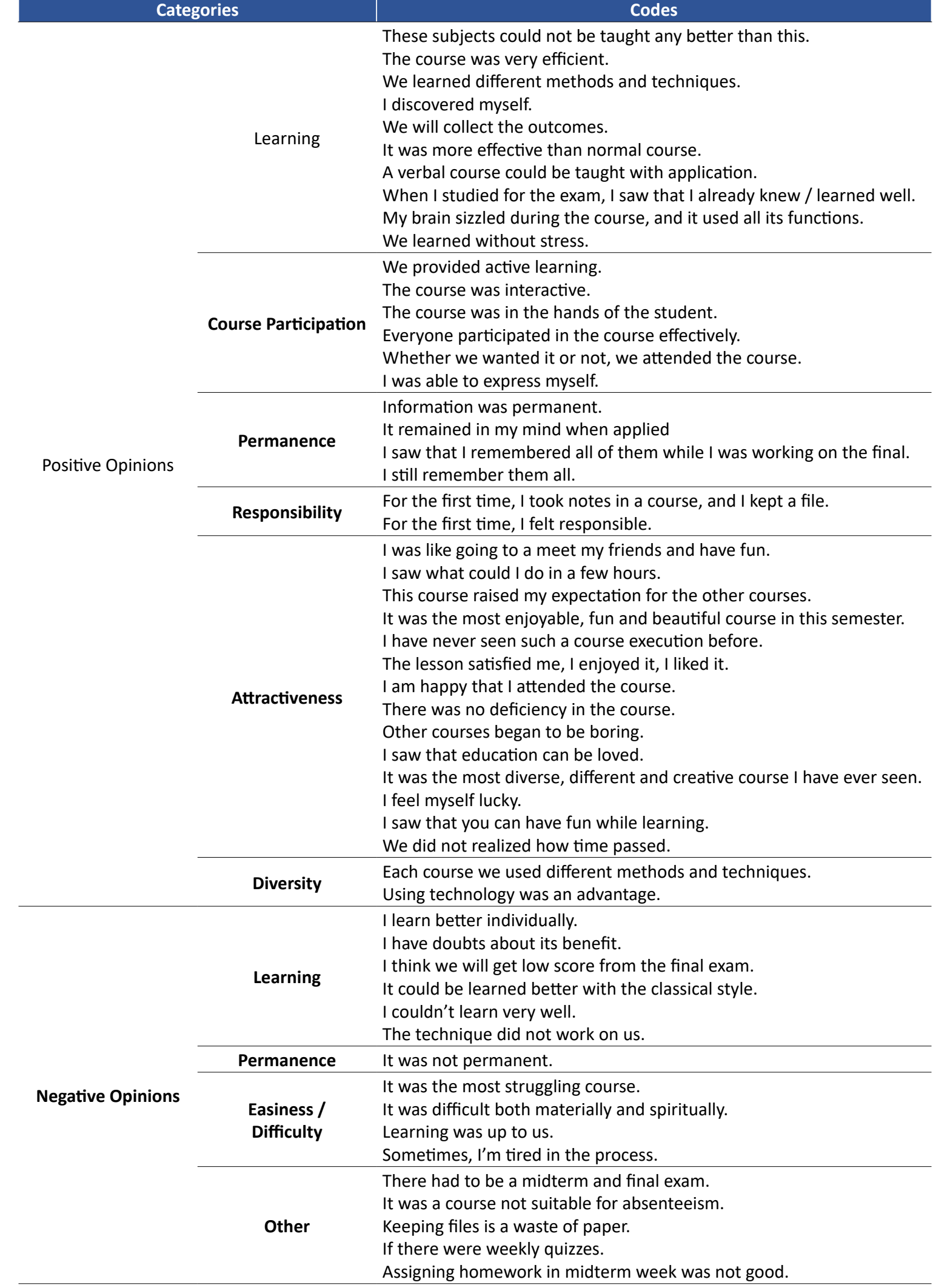

Table 14: Opinions on the Design of the Course

As can be seen in Table 14, students' opinions on activities learning, the students find the course efficient, they learn consist of two categories which are "positive opinions" and the subjects well, and they learn without stress. In addition, "negative opinions".

It is seen that students have positive and negative opinions classical learning, plain lecturing and taking notes. about the design of the course. It is observed that about the It is seen that the students find the course to be very positive in $\begin{array}{rr}\text { Electronic ISSN } & \text { Printed ISSN } \\ \mathbf{1 8 0 3 - 1 6 1 7} & \mathbf{2 3 3 6 - 2 3 7 5}\end{array}$

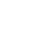
be nice, but it is nice as long as everyone is aware of say that I sometimes had minor problems in this regard." S10: "The activities were very fun... However, having
limited course time caused some activities to be done in a

It is observed that opinions of students in the third group,

\section{Opinions on the Design of the Course}

design of the course were given in Table 14:
S7: "Yes, doing homework or activities as a group can were done in groups are gathered under three categories which 
terms of attendance. It is observed that students have positive is the most challenging, it is tiring and sometimes it is opinions that they participate the course no matter if they want to or not, that they express themselves, that the course students. The students think that the information is perthe and state that they feel a sense of responsibility in this course. It is noteworthy that the sub-category with the highest desity is the attraction category. It is seen that the students liked the course and the conduction of the course. The students state that they had a lot of fun in the course, they were very surprised about the process, and they did not understend how time passed in the course. Students indicated that after this course, their expectations from other courses have increased, that other courses have started to be boring and that they see that with the help of this course education can be liked. These indications of the students showed how much they liked this indication

The difficulty of the course is the thing that students complain most. It is seen that some of the students think that the course frustrating.

direct quotes from students' opinions under these egories were given below:

S1: "Good thing, I learned this way. I discovered many areas where I was successful. Most importantly, we learned what group work is. Do you thow thet we worked shoulder to shoulder with many of our Jriends that we did

S3: "I am one of the most delighted with these activities. Because, I think the course should be in the student's And this course made me very satisfied in this sense."

\section{Opinions about the Pre-Course Tasks}

The opinions of the students in the third group regarding the pre-course tasks were given in Table 15: friends that we did not communicate, and learned all

\begin{tabular}{|c|c|c|}
\hline \multirow[b]{3}{*}{ Positive Opinions } & & Codes \\
\hline & Videos & $\begin{array}{l}\text { I watched the places I don't understand again. } \\
\text { Watching videos before coming to the class provided learning. } \\
\text { The videos increased the efficiency. } \\
\text { The videos enabled regular studying. } \\
\text { Learning a home with videos was good in every respect. } \\
\text { The learning environment at home was comfortable with videos. } \\
\text { I watched the video as much as I wanted whenever I wanted. }\end{array}$ \\
\hline & Homework & $\begin{array}{l}\text { Homework was too much. } \\
\text { Homework has contributed a lot to me. } \\
\text { Homework made us come to course ready. } \\
\text { Homework was useful. } \\
\text { Homework was efficient. } \\
\text { It was useful to give feedback on homework. } \\
\text { Very good feedback was given to our homework. } \\
\text { Reading the articles was enjoyable. }\end{array}$ \\
\hline \multirow[b]{2}{*}{ Negative Opinions } & Videos & $\begin{array}{l}\text { It was difficult to watch the videos in unfavorable dormitory } \\
\text { conditions. } \\
\text { Although it was good at first, it later became unbearable. } \\
\text { It was not suitable for this course because it was verbal. } \\
\text { Presentations should be given instead of videos. } \\
\text { The more examples should have been given in the videos. } \\
\text { If quizzes were done from videos. } \\
\text { Presentations should also be given along with the videos. }\end{array}$ \\
\hline & Homework & $\begin{array}{l}\text { Regular homework mode forced me, and I was not accustomed to } \\
\text { Homework sometimes seemed like cruelty. } \\
\text { Homework was too much and boring. } \\
\text { Homework was done at the last moment / last day. } \\
\text { Homework was tiring. } \\
\text { I was yelling while doing homework. } \\
\text { I felt lazy to do homework. } \\
\text { I didnetimes had trouble creating examples. } \\
\text { We said "homewmork agaize subjects. }\end{array}$ \\
\hline
\end{tabular}

\section{Table 15: Opinions about the Pre-Course tasks}

As can be seen in Table 15, students' opinions on pre-course tasks. The students think that the videos activities consist of two categories which are "positive given to take home were useful for learning. They also think that he videos allow them to watch them anytime, Students have both positive and negative opinions about wherever they want, and watch them over and over

again. It is observed that some of the students prefe presentations instead of videos to be given. They have some difficulties while watching the videos in the dormitory.

It is seen that in general, students find homework efficient and useful in terms of preparation and learning, but it is also seen that some students get tired, struggled and bored while doing homework.

Some direct quotes from students' opinions under these categories were given below:

\begin{tabular}{|c|c|c|}
\hline \multicolumn{2}{|c|}{ Categories } & Codes \\
\hline \multirow{4}{*}{ Positive Opinions } & Learning & $\begin{array}{l}\text { Activities made a great contribution to learning. } \\
\text { The activities were instructive. } \\
\text { The activities were efficient. } \\
\text { l learned easily through activities. } \\
\text { The subject was strengthened well with the activities. } \\
\text { I understood the subject better with the activities. } \\
\text { What was learned at home was reinforced. }\end{array}$ \\
\hline & Participation & $\begin{array}{l}\text { Even when I came to the course feeling tired, I loved the activities. } \\
\text { I am very happy to attend different activities. }\end{array}$ \\
\hline & Attractiveness & $\begin{array}{l}\text { It was fun to listen to friends' activities. } \\
\text { The course became entertaining with activity. } \\
\text { It increased my interest in the course. } \\
\text { I have never done so much activity in my previous education life. } \\
\text { The activities were very enjoyable, fun. } \\
\text { I enjoyed the activities. } \\
\text { With the activities, I did not understand how the course is finished. } \\
\text { Methods and techniques were very good. }\end{array}$ \\
\hline & Group Interaction & 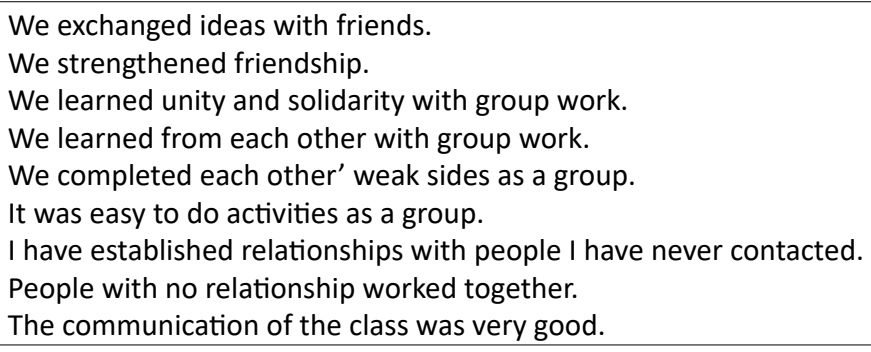 \\
\hline \multirow{3}{*}{ Negative Opinions } & Learning & $\begin{array}{l}\text { Some activities were left unfinished. } \\
\text { The activities were not instructive. }\end{array}$ \\
\hline & Limited Time & $\begin{array}{l}\text { The time given at the activities was very short. } \\
\text { The activities were done very fast, it was a rush of breeding. }\end{array}$ \\
\hline & Workload & $\begin{array}{l}\text { The number of activities could have been smaller. } \\
\text { The high number of activities prevented satisfaction. } \\
\text { We were very tired with the activities. }\end{array}$ \\
\hline
\end{tabular}

\section{Table 16: Opinions About Activities}

16: "First of all, when I listened to the lecture videos and do homework every week beforehand, I would

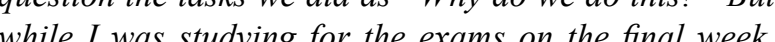
I realized that it really helped me a lot." -

ches and doing homework before to work regularly...

\section{Opinions About Activitie}

The opinions of the students in the third group regarding the activities were given in Table 16:

As can be seen in Table 16, students' opinions on the activities think that the course became fun with the activities, that their belonged to one of two categories, which are "positive opinions" and "negative opinions".

The students have both positive and ngative views about the activities, but the positive views are decidedly high. Students

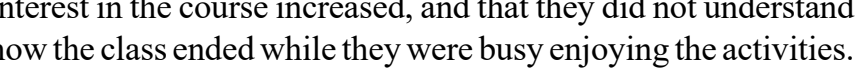
whe class ended while they were busy enjoying the activities. and strenghened what they learned at home. However, some from each onthe to unity and ogenthess, and to socialization. students think that they could not learn through activities. It is The students also have some negative opinions about the observed that the students participated in the course through duration of activities being short and the number of activities the activities and found the activities very attractive. Students being high. 

Some direct quotes revealing students' opinions within these
categories are given below:

S15: "For the first time, I took notes in a course. I organized a flie. I felt responsible for a course. you did. Although weeks have passed, I still

29: "I am sure that if we had done this course in been learned so easily and it would not have been so permanent. With the activities we did in the course

we coded each subject with something in our mind."

\section{DISCUSSION}

The following conclusions were reached regarding the effect

of the models used on academic success:
First of all, it was concluded that there was no significan difference between the posttest success scores of the groups, that the students "levels of learning success were close to each other, and that the students in the whole group learned
well. This shows that the three different applications arranged according to student-centered approaches had positive effects on success, although their levels were different. Other studies have shown that student-centered education increases students' academic achievement, increases their motivation to learn, increases the level of knowledge recall, and provides in-depth understanding (Kilic and Sahin, 2016; Maden, Durukan and Akbas, 2011; Salinas, Kane-Johnson and VasilMiller, 2008; Smart and Csapo, 2007).

It was also concluded that the standard deviation was smaller in the group in which the flipped learning model was applied compared to the other two groups. Senemoğlu (2011) stated that the fact that almost all of the students participated in the teaching showed that the quality of the teaching service was at a very good level, and the degree of students' participation in the teaching-learning process is the best indicator of the quality of teaching service. Furthermore, when students are able to participate in the teaching-learning process at the highest level, the majority of students learn at the highest level and their success levels are close to each other. This shows that the flipped learning model is effective on students' success. In terms of academic success, the flipped learning model and traditional classes have been the subject of many studies. In the literature, there are studies stating that flipped learning increases students' academic success (Asiksoy and Sorakın, 2018; Bishop and Verleger, 2013; Butt, 2014 Mason, Shuman and Cook, 2013; Okmen, 2020). Cho and Lee (2018) also reached the conclusion that this model has a positive

At the end of the present research, the results regarding the opinions of the students in the first group, where the lessons were taught through presentations interactively with the students, were as follow:

First, it was concluded that the students found the examples given in the lessons and the stories and memories that were classroom had negative effects and caused them anxiety about not learning. It was seen that because the reading an not realistic to ask students to read and learn the subject in the classroom in a limited and insufficient amount of time, and it was not effective in learning. This also supported the effectiveness of learning the subjects in the flipped learning model in the home environment before the lesson, whenever the students wanted.

The students did not find activities done without understanding the subject instructive, and the short duration and the high number of activities made it difficult for the students to follow the activities and had a negative effect on their learning. The fact that there was a shortage of time both for the reading task given at the beginning of the lessons and for the activities indicates that the classroom time was not sufficient for both understanding the lesson and doing activities. This again emphasizes the effectiveness of performing the understanding comprehension parts of the lessons at home before class and allocating more time for activities as in flipped learning. The opinions of the students in the third group, where the flipped learning model was applied, were found to be as follows:

First, it was concluded that the students liked the lessons and the teaching of the lessons very much, found the lessons efficient, had fun in the lessons, and were surprised at how quickly time passed in class. This shows that the flipped learning model had a positive effect on students' attitudes towards the lessons. Numerous studies in the literature have also shown that the flipped learning model positively affects students' attitudes and motivations towards the lesson (Che et al., 2015; Clark, 2015; Gross et al. 2015; Heyborne and Perrett, 2016; Ojennus, 2016; Okmen, 2020; Tawfik and Lilly, 2015).

The students found home videos and homework useful for lesson preparation and learning, and even if they felt forced and bored, they had positive thoughts about watching the videos whenever they wanted, watching them wherever they wanted, and watching them again and again. Although there are studies in the literature reporting that the obligation to work at home in the flipped learning model is a disadvantage of this model (Alsancak Sirakaya, 2015; Rowkaya, 2017; Turan and Goktas, 2015), a large number of students stated that the work done at home increased their active participation and success (Frydenberg, 2012; Herold et al., 2012; Okmen, 2020; Stone, 2012; Talbert, 2012).

The students also thought that the activities were effective in their learning and reinforced what they had learned at home, while the lessons became fun with the activities and increased their interest and participation in the lessons. The group studies contributed to their exchanges of ideas with their friend and helped them get to know each other, learn from each other, gain responsibility, build unity and togetherness, and socialize; the only negative situation related to the activities was the shortage of time. Studies show that methods that require students to work with each other increase students' achievents (Nam and Zellwe, 2011; Okmen, 2020, ShyJong, 2007) and motivations (Arısoy, 2011; Okmen, 2020).
Scott, Buchanan, and Haigh (1997) also stated that teaching practices in which the students are active, rather than the eacher, create more effective and permanent learning.

In the literature, it has been reported that there may be in classro classroom management and time management (Danisman et al 2017) and that some students may not be able to complete their projects because the speed of the students to fulfill the tasks is not equal. For the same reason, they then have to wait in the classroom, they may become bored (Danisman et al., 2017; Thoms, 2012).

Based on the results obtained throughout this research, various suggestions can be presented. Some of them are as should be prepared to keep students active and practicing, and to attract students' attention. Group activities should be included in the teaching process. Lectures should be enriched with different examples and stories. Teachers should enrich their general teaching styles with regard to their own subject students the opportunity to repeat and reinforce subjects. Home tasks should be prepared to be completed within half an hour. Class tasks should be prepared while ensuring that CONCLUSION

This research has shown us that different methods used according to the student-centered approach have positive for which the flipped learning model was applied, the majority of the students learned at a high level and their
success levels were close to each other. This shows that a high quality of education was provided in this group. Alhough the students found the examples, the stories, and the mese were not in the lectures to be interesting and good, nd the sertion, system that they have grown up with.

was seen that not enough time could be given to both lectures and activities, and activities performed without understanding the subject sufficiently were not found to be (c) the step of the lesson to be carried out at home betore the
lesson and accordingly allows more time for activites in the lisson. of the lessars the course. The students liked the teaching sure lessons very much, had fun in the lessons, and were surped at how quickly time passed. Group work allowed the students to exchange ideas with their friends, learn from and socialize.
The flipped leaning model positively affected the students' 


\section{REFERENCES}

Alsancak Sirakaya, D. (2015) The effect of flipped classroom model Demir, E., Saatcioğlu, Ö. and İmrol, F. (2016) 'Examination of on academic achievement, self-directed learning readiness and Educational Researches Published in International Journals in

Arisoy, B. (2011). The effects of STAD and TGT techniques of cooperative learning on sixth grade students? academic
achievement, retention and social skill levels in ?istatistic and probability? subject in mathematics lesson. Unpublished master thesis, Adana: Cukurova University.

Assksoy, G. and Sorakın, Y. (2018) 'The Effects of Clicker-Aided Flipped Classroom Model on Learning Achievement, Physic Anxiety and Students' Perceptions', International Online Journal of Education and Teaching, Vol. 5, No. 2, pp. 334-346.

Baepler, P., Walker, J. D. and Driessen, M. (2014) 'It's Not About Seat Time: Blending, Flipping, and Efficiency in Active Learning Classrooms, Computers \& Education, Vol. 78, pp. 227-236. hitps://doi.org/10.1016/j.compedu.2014.06.006

Baltac1, A. (2018) 'A Conceptual Review of Sampling Methods and Sample Size Problems in Qualltative Research', Journal of Bitl s Eren University Institute of Social Sciences, Vol. 7, No. 1, pp.

Benson, P. (2012) 'Learner-centered teaching', in A. Burns and J.C. Richards (ed.) The Cambridge Guide to Pedagogy and Practice in Second Language Teaching, Cambridge, UK: Cambridge

Bergmann, J. and Sams, A. (2012) Flip Your Classroom: Reach Every Student in Every Class Every Day, Washington, DC: Interna
Society for Technology in Education.

Bishop, J. L. and Verleger, M. A. (2013) 'The Flipped Classroom: A Survey of the Research', $120^{\text {th }}$ ASEE Annual Conference and on, Atlanta, GA

Butt, A. (2014) 'Student Views on the Use of a Flipped Classroon Approach: Evidence From Australia',
Accreditation, Vol. 6, No. 1, pp. 33-43.

Buyukalan Filiz, S., Celik, S. and Toraman, C. (2018) 'Developing inclass question asking techniques scale (ICQATS'), The Journal
of Turkish Educational Sciences, Vol. 16, No. 2, pp. 197-212.

Buyukozturk, S., Kilic Cakmak, E., Akgun, O. E., Karadeniz, S. and Demirel, F. (2013) Bilimsel Araşttrma Yöntemleri. 15th ed. Ankara: Pegem Akadem

Chen, S., She, J., Kameda, H. and Ohno, S. (2015) 'Implementatio and Evaluation of Flipped Classroom in Chinese Language Course', Proceedings of the Multidisciplinary Academic Conference, pp. 1-8.

Cho, B. and Lee, J. (2018) 'A meta analysis on effects of flipped learning in Korea', Journal of Digital Convergence, Vol. 16,

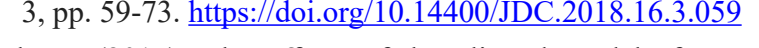

Clark, K. (2015) 'The Effects of the Flipped Model of Instruction
on Student Engagement and Performance in the Secondary on Student Engagement and Performance in the Secondary Mathematics Classroom', The Journal of Educators Online,
12, No. 1, pp. 1-115. https://doi.org/10.9743/JEO.2015.1.5

Daley, B. J. (2003) 'A Case for Learner-Centered Teaching and Vol. 98, pp. 23-30. https://doi.org/10.1002/ace.96

Danisman, Ş., Hasirrc Eriş, H.M., Kırcaburun, K., Boyac1, Z., Sahin S., Okmen, B. and Kilic, A. (2017) 'Investigation of Flipped Learning Approach According to Expert Opinions', Journal of Education and Practice, Vol. 8, No. 26, pp. 81-90.

Kaplan, B. (2006) The Effect of Homework to Success of Students and Style. Unpublished master thesis Istanbul: Marmara University.

Kilic, A., Aydn, M., Okmen, B. and Sahin, S. (2019) Kuramdan Uygulamaya ihtiyaç Belirleme. Ankara: Pegem Akademi.

Kilic, A. and Sahin, S. (2016) 'The Effects of Religious Culture and Moral Knowledge Course Organized with Student-Centered Approach on
Students' Academic Achievement and Attitudes', Journal of Theory and Practice in Education, Vol. 12, No. 1, pp. 41-62.

Kubat, U. (2018) 'If There is Question, There is Learning Too', Electronic Journal Of Social Sciences', Vol. 17, No. 68, pp.
1585-1598. https://doi.org/10.17755/esosder.396548
Lazonder, A. W. and Harmsen, R. (2016) 'Meta-analysis of Inquiry-Based Learning: Effects of Guidance', Review Of
Educational Research, Vol. 86, No. 3, pp. 681-718. https://doi. org /10.3102/0034654315627366 on International.

Maden, S., Durukan, E. and Akbas, E. (2011) 'Primary School , Mustafu 16, pp. 255-269.

Mason, G., Shuman, T. R. and Cook, K. E. (2013). 'Inverting (Flipping) Classrooms Advantages and Challenges', 120th ASE Annual Conference ve Exhibition, Atlant

McCallum, S., Schultz, J., Sellke, K. and Spartz, J. (2015) 'An Examination of the Flipped Classroom Approach on College Student Academic Involvement', International Journal of Teaching and Learning in Higher Education, Vol. 27, No. 1, pp. $2-55$

Miles, M. B. and Huberman, A. M. (1994) Qualitative Data Analysis: An Expanded Sourcebook. 2nd edn. Thousand Oaks: Sage

Nam, C.W. and Zellner, R.D. (2011) 'The Relative Effects of Positive Interdependence and Group Processing on Student Achievemen and Attitude in Online Cooperative Learning, Computers Education, Vol. 56, No.

Nemtchinova, E. (2007) 'Using technology with young English anguage learners' in Gordon, T., Fromberg, D. P. and William
R. (eds) Teaching Young Children a Second Language, Connecticut: Praeger

Neuendorf, K. A. and Kumar, A. (2002) 'Content Analysis', The International Encyclopedia of Political Communication, pp.
221-230. https://doi.org/10.1002/9781118541555.wbiepc065 Biochemistry Classroom', Biochemistry and Molecular Biolog Education, Vol. 44, No. 1, pp. 20-27. https://doi.org/10.1002 bmb.20926

Okmen, B. (2020) Developing the instructional process in layered fipped learning model. Unpublished PhD thesis, Duzce: Duzce

Rodriguez-Valls, F. and Ponce, G. (2013) 'Classroom, the we space; Developing studentcentered practices for second languag learner (sll) students, Educalion Policy Analysis Archives, Vol

Sahin, S.. (2020). Compassionate love, democracy and studen principals. Unpublished PhD thesis, Duzce: Duzce University Institue of Social Sciences.

Salinas, M. F, Kane-Johnson, S. E. and Vasil-Miller, M. A. (2008) 'Long-term Learning, Achievement Tests, and Learner Centere Instruction', Journal of the Scholarship of Teaching and Learning, Vol. 8, No. 3, pp. 20-28.

Sams, A. and Bergmann, J. (2013) 'Flip Your Students' Learning', Educational Leadership, Vol. 70, №. 6, pp. 16-20.
Leedy, P. D. and Ormrod, J. E. (2005) Practical Research. NJ: Pearson

Sarrgöz, O. (2011) 'Assessment of the Thoughts of Secondary Education Students about Homeworks Given in Chemistry Lesson, Electo $80-87$.

Scott, J., Buchanan, J. and Haigh, N. (1997) 'Reflections on StudentCentered Learning in a Large Class Setting', British Journal of org $/ 10.1111 / 1467-8535.00003$

Senemoğlu, N. (2011) Kuramdan Uygulamaya Gelisim Öğrenme ve Ögretim, Ankara: Pegem Akademi Yayincllik.

Shy-Jong, J. (2007) 'A Study of Students Construction of Science Knowledge: Talk and Writing in a Collobrative Group', Educational Research, Vol. 49,
org/10.1080/0013188070120078

Sirakaya, D. A. (2017) 'Student Views on Gamified Flipped Classroom Model', Ondokuz Mayis University Journal of Faculty of Education, Vol. 36, No. 1, pp. 114-132. https://doi. org/10.7822/omuefd.

Smart, K. L. and Csapo, N. (2007) 'Learning by Doing: Engaging Students Through Learner-Centered Activities', Busines Communication Quarterly, Vol. 70, No. 1, pp. 451-457. https:///

Stone, B. B. (2012) 'Flip Your Classroom to Increase Active Learning and Student Engagement', 28th Annual Conference on Distance University of Wiscon

Learning System for Improving the 'A Mobile Gamification Achievements', Journal of Computer Assisted Learning, Vol. 31, No. 3, pp. 268-286. https://doi.org/10.1111/jcal.12088

pp. 1-3.

Afik, A. A. and Lilly, C. (2015) 'Using a Flipped Classroom Approach to Support Probl.

Thoms, C. L. (2012) 'Enhancing the Blended Learning Curriculum by Using the Flipped Classroom Approach to Produce a Dynamic Learning Environment', Iceri2012 Proceedings, pp. 2150-2157.

incer, B. (2012) 'The Flipped Classroom: Online Instruction at No. 1, pp. 82

uran, Z. and Goktas, Y. (2015) 'A New Approach in Higher Education: The Students' Views on Flipped Classroom Method'. Journal of Higher Education and Science, Vol.
164. http://dx.doi.org/10.5961/jhes.2015.118

Vernon, DT and Blake, R. (1993) 'Does Problem-Based Vernon, D.T. and Blake, R.L. (1993) 'Does Problem-Based
Learning Work? A Meta-Analysis of Evaluative Research', Learning Work? A Meta-Analysis of Evaluative Research',
Academic Medicine, Vol. 68, No. 7, pp. 550-563. http://dx.doi. org /10.1097/00001888-199307000-00015 ald $10.1097 / 00001888-199307000-00015$

(2) Stews about Gamification Based Curriculum for the Lesson of Teaching Principles and
Methods', International Journal of Curriculum and Instructional Studies, Vol. 6, No. 11, pp. 85-101. 